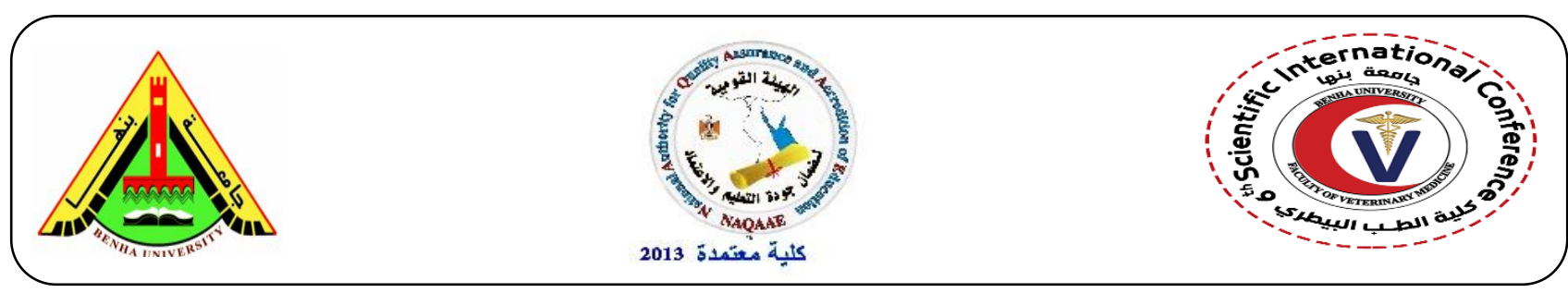

\title{
Oxidative Stress and Antioxidant Activity in Buffaloes with Post parturient Hemoglobinuria
}

\author{
Hayat Fayed*, M. M. Ghanem, Y. M. Abdel-Raof and H. M. El-Attar. \\ Department of animal medicine, Faculty of Veterinary Medicine, Benha University, Egypt. \\ Correspondence: * (Hayat.Fayed@fvtm.bu.edu.eg)
}

\section{A B S T R A C T}

The study aims to assess the relation between oxidative stress, antioxidant activity and post parturient hemoglobinuria on 70 hemoglobinuria and 30 apparently healthy buffaloes. Blood and serum samples were collected and tested for various parameters of oxidative stress and antioxidant enzymes. Significant increase in erythrocytic MDA (malondialdehyde) whereas significant decrease in serum inorganic phosphorus, copper $(\mathrm{Cu})$, selenium $(\mathrm{Se})$, erythrocytic SOD (superoxide dismutase), GPX (glutathione peroxidase) and G6PD (glucose-6-phosphate dehydrogenase). According to these results, there was increase in oxidative stress indicator while antioxidant enzymes activities dramatically decreased in post parturient hemoglobinuria (PPH) affected buffaloes. It was concluded that there is relation between oxidative stress, antioxidant activity and PPH in buffaloes.

Key words: Buffaloes, post parturient hemoglobinuria, oxidative stress, antioxidant enzymes.

(http://www.bvmj.bu.edu.eg)

(BVMJ-34(3): 57-63, 2018)

\section{INTRODUCTION}

Phosphorous $(\mathrm{P})$ is an essential mineral that is involved in various biological functions such as energy metabolism pathways, DNA and RNA synthesis, bone formation and cell signaling (Hill et al., 2008). Oxidative phosphorylation, oxygen delivery, glycolysis, and maintenance of cellular structural integrity are among the processes that require $\mathrm{P}$ (Grünberg, 2008). Copper is a cofactor of several metalloenzymes such as SOD which play vital role in the prevention of oxidative tissue damage (Minatel and Carfagnini, 2002). Copper deficiency is also an etiological factor of $\mathrm{PPH}$, as its deficiency reduces the activity of the copper containing enzyme, superoxide dismutase, which is part of the erythrocyte protection mechanism against oxidative stress (Heuer and Bode, 1998). Oxidative stress occurs due to the diminished capacity of antioxidant 


\section{Fayed et al., 2018 (BVMJ-34(3): 57-63)}

defense of the body and/or increased production of free radicals such as reactive oxygen species and/ or reactive nitrogen species (ROS/RNS) (Santra et al., 2000). Oxidative stress as it is not a classical disease, does not exhibit a specific clinical picture. It has been observed that during the transition period ruminant can experience oxidative stress which may contribute to periparturient disorders and may be associated with metabolic diseases (Ronchi et al., 2000). Oxidative stress plays a key role in the onset or progression of numerous animal diseases. Ruminant undergo this deleterious process mainly during the peripartal period. The period of transition between late pregnancy and early lactation is associated with lipid and protein metabolic changes (Castillo et al., 2006). In postparturient hemoglobinuria affected buffaloes, markers of oxidative stress enhanced while antioxidant enzymes activity decreased (Chugh et al., 2000).

Therefore, this work aimed to evaluate the relation between oxidative stress, antioxidant enzymes activity and post parturient hemoglobinuria.

\section{MATERIAL AND METHODS}

\subsection{Animals}

Seventy buffaloes suffering from PPH were randomly selected from field cases in many localities in province of El-qalyubia during spring (season of berseem feeding) from 2016 to 2018, 30 clinically healthy buffaloes of similar description from the same areas were included for case control study. Animals of the study were feeding on stall fed, and berseem. Hemoglobinuria is the most characteristic clinical sign based on it the disease was clinically diagnosed during advanced pregnancy or early lactation. Diseases that clinically characterized by a reddish discoloration of urine, such as babesiosis, leptospirosis, and bacillary hemoglobinuria, were excluded by laboratory tests.

\subsection{Samples}

Blood samples were collected from jugular vein according to (Kelly, 1984).

\subsubsection{Serum samples:}

Blood sample was taken by allowing about $5 \mathrm{ml}$ of blood to flow freely and gently over the inner surface of a clean and dry centrifuge tube. The samples were allowed to clot in slanting position at room temperature for about 2 hours then the samples were centrifuged at $3000 \mathrm{rpm}$ for 10 minutes, the clear sera were aspirated carefully and transferred into clear dry labeled eppendorf tubes and stored at $-20 \circ \mathrm{C}$ till examination. Used for the biochemical determination of serum inorganic phosphorus, copper and selenium.

\subsubsection{Lysate samples:}

The blood samples were collected in vacutainer tubes with heparin for determination of erythrocyte MDA, SOD, G6PD and GPx activities in the lysate. Erythrocyte lysate was obtained from centrifugation of the blood sample at $1000 \mathrm{rpm}$ for 10 minutes for separation of plasma. The erythrocytes were lysed in 4 times its volume of ice cold HPLC grade water Centrifuged at 10,000 for 15 minutes at $4{ }^{\circ} \mathrm{C}$. Erythrocytes lysate was then collected and stored at $-80 \circ \mathrm{C}$ till analysis according to (Nishikimi et al., 1972).

\subsubsection{Biochemical analysis}

The serum samples were used for spectrophotometric determination of Inorganic phosphorus (Anderson and Cockayne, 1993), copper (Veldman et al., (2000) and selenium 
(Brodie, 1977) while the lysate samples were used for determination of erythrocytic MDA (Esterbauer et al., 1982), Erythrocytic SOD (kakkar et al., 1984), Erythrocytic GPX (Chiu et al., 1976) and Erythrocytic G6PD (Morelli et al.,

1978).

Statistic alanalysis

The data were statically analyzed using Ttest in the study as previously described by Bailey (2008). We used SPSS version 16 software to conduct this analysis. Values were represented as means \pm standard error (SE). All differences were considered significantly among groups of the experimental study when $P \leq 0.05$.

\section{RESULTS:}

In PPH affected buffaloes, serum inorganic phosphorus, copper, selenium levels and erythrocytic SOD, GPX, G6PD enzymes activity were significantly $(\mathrm{p} \leq 0.05)$ lower when compared by healthy buffaloes, while MDA level in red blood cells was significantly $(p \leq$ 0.05 ) higher than in the healthy ones (Table 1).

Table (1): Biochemical analysis of control and post parturient hemoglobinuria affected buffaloes (Means \pm S.E.).

\begin{tabular}{cccc}
\hline & Control & PPH & P value \\
\hline $\mathrm{P} \mathrm{mg} / \mathrm{dl}$ & $5.44 \pm 0.21 \mathrm{a}$ & $2.00 \pm 0.06 \mathrm{~b}$ & $<0.001$ \\
\hline Copper $\mu \mathrm{g} / \mathrm{dl}$ & $119.35 \pm 2.71 \mathrm{a}$ & $74.00 \pm 2.18 \mathrm{~b}$ & $<0.001$ \\
\hline Selenium $\mu \mathrm{g} / \mathrm{dl}$ & $21.09 \pm 0.46 \mathrm{a}$ & $14.29 \pm 0.38 \mathrm{~b}$ & $<0.001$ \\
\hline $\mathrm{MDA} \mathrm{nmol} / \mathrm{g} \mathrm{Hb}$ & $37.76 \pm 0.84 \mathrm{~b}$ & $90.98 \pm 2.18 \mathrm{a}$ & $<0.001$ \\
\hline $\mathrm{SOD} \mathrm{U} / \mathrm{mg} \mathrm{Hb}$ & $4.14 \pm 0.14 \mathrm{a}$ & $1.19 \pm 0.07 \mathrm{~b}$ & $<0.001$ \\
\hline GPX U/mg Hb & $83.27 \pm 1.24 \mathrm{a}$ & $35.83 \pm 1.09 \mathrm{~b}$ & $<0.001$ \\
\hline G6PD U/g Hb & $5.34 \pm 0.15 \mathrm{a}$ & $1.41 \pm 0.12 \mathrm{~b}$ & $<0.001$ \\
\hline -Values with different superscript letters within the same row were statistically \\
significant at $p<0.05$.
\end{tabular}

\section{DISCUSSION:}

Significant decrease of serum inorganic phosphorus in post parturient hemoglobinuria affected buffaloes. Our data were agreeable with Dalir-Naghadeh et al. (2005). PPH mostly affects buffaloes either in advanced pregnancy or in early lactation with majority of animals are in their $3^{\text {rd }}$ to $6^{\text {th }}$ lactations. Hypophosphataemia could be attributed to utilization of $\mathrm{P}$ for foetal bone development and its heavy drainage through the milk in high producing animals maintained on low phosphorus diet. Disease is strongly associated with berseem feeding in winter season Akhtar et al. (2006). 


\section{Fayed et al., 2018 (BVMJ-34(3): 57-63)}

Oxidative phosphorylation, oxygen delivery, glycolysis, and maintenance of cellular structural integrity are among the processes that require $\mathrm{P}$ (Grünberg, 2008).

In PHH, red blood cells were lysed most probably due to their exposure to altered function and structure, a loss of normal deformability and an increase on fragility due to impaired glycolysis and ATP synthesis Bhikane et al. (2011).

Serum copper and selenium levels in PPH affected buffaloes were significantly lower than healthy ones. These data were agreeable with Akhtar et al. (2007).

Minerals are involved in tissue defense mechanisms against free radical damage to biological systems. Several metalloenzymes, which include glutathione peroxidase (Se), catalase $(\mathrm{Fe})$, and superoxide dismutase $(\mathrm{Cu})$, are also critical in protecting the internal constituents from oxidative damage Han et al. (2006).

Lower the erythrocytic SOD, GPX and G6PD enzymes activity in PHH affected buffaloes. These findings are come in accordance with Gahlawat (1998), Singh et al. (2005) and Khan and Akhtar (2007).

Antioxidants may act by scavenging the radicals directly and sustaining the activity of antioxidant enzymes or inhibiting the activity of oxidizing enzymes Dedra et al. (2004).

Antioxidant enzymes such as SOD and GPX had been an important role in evaluating of oxidative stress Kleczkowski et al. (2003).

SOD and GPX enzymes represent the major antioxidant defense components in protecting the cells against increased ROS. Superoxide dismutase catalysis the dismutation of superoxide radical to hydrogen peroxide which is further metabolized to water by GPX enzyme Bernabucci et al. (2005).

Parturient hemoglobinuria (PHU) affected buffaloes usually suffer from severe anemia and hypophosphatemia and erythrocytes with significantly reduced G6PD are prone to hemolysis leading to hemoglobinuria in buffaloes Akhtar et al. (2007).

G6PD, the principal source of NADPH, serves as an antioxidant enzyme to modulate nitric oxide synthase activity. Deficient G6PD activity is associated with increased endothelial cell oxidant stress. G6PD, the first and ratelimiting enzyme of the pentose phosphate pathway, catalyzes the synthesis of riboses for nucleic acid production and is the principal intracellular source of NADPH. NADPH, in turn, is used as a reducing equivalent to maintain reduced glutathione stores (GSH), which are used to scavenge reactive oxygen species (ROS). ROS are buffered intracellularly by converting GSH to its oxidized form (GSSG) in a reaction catalyzed by GPX. GSSG is recycled to GSH by glutathione reductase (GSSG reductase), which requires $\mathrm{NADPH}$ as a cofactor Leopold et al. (2003).

The significant decreased values of erythrocytic G6PD activity might be due to the disturbed glutathione redox system due to an important enzyme in cellular metabolism in the first and rate-limiting step of pentose-phosphate pathway. Among the functions of this pathway is the protection of cells from oxidative stress, through its role in conversion of NADP to $\mathrm{NADPH}$, thereby replenishing the levels of reduced glutathione to protect against lipid peroxidation Cappellini and Fiorelli (2008). 


\section{Oxidative Stress and Antioxidant Activity in Buffaloes with Post parturient Hemoglobinuria}

Reactive oxygen species (ROS) are constantly generated by cells and ROS-derived damage. Protection against oxidative damage largely relies on the reductive power of NAPDH, whose levels are mostly determined by the enzyme G6PD Nobrega-Pereira et al. (2016).

Erythrocytic MDA level in PPH affected buffaloes was significantly increased. This finding coincided with Gahlawat et al. (2001) and Sarma et al. (2014).

Increased MDA concentration in erythrocytes of ruminant may be an indication of elevated oxidative stress. High levels of MDA have been associated with the severity of anemia (Asri- Rezaei and Dalir-Naghadeh, 2006).

The malondialdehyde (LPO) levels in erythrocytes of haemoglobinuric buffaloes were significantly increased and lowered levels of reduced glutathione in erythrocytes of haemoglobinuric buffaloes. Phosphorus deficiency decreases the glucose utilization rate and ATP production by erythrocytes leading to decrease in synthesis as well as reduction of glutathione which predisposes the erythrocytes to adverse effects of oxidants (Gahlawat et al., 2007).

\section{CONCLUSION:}

Based on the obtained results of this study, there was relation between oxidative stress, antioxidant activity and PPH in buffaloes. PPH could be considered as stress condition on the animals that could alter the oxidative and antioxidant status.

\section{REFERENCES:}

Akhtar, M. Z.; Khan, A.; Sarwar, M. and Javaid, A. (2007): Influence of Soil and Forage Minerals on Buffalo (Bubalus bubalis) Parturient Haemoglobinuria. Asian-Aust. J. Anim. Sci. 20(3) Pp: 393 398.

Akhtar, M. Z.; Khan, A.; Zaman, T. and Ahmad, N. (2006): Some clinico-epidemiological and biochemical observations of parturient haemoglobinuria in NiliRavi buffaloes (Bubalus bubalis). Pakistan Vet. J. 26 (4) Pp: 151-156.

Akhtar, M.Z.; Khan, A.; Sarwar, M. and Javaid, A. (2007): Influence of Soil and Forage Minerals on Buffalo (Bubalus bubalis) Parturient Haemoglobinuria. Asian-Aust. J. Anim. Sci. 20 (3) Pp: 393 - 398.

Anderson, S. C. and Cockayne, S. (1993): Clinical chemistry concepts and applications. W.B. Saunders Company, Philadelphia, London, Toronto, Montreal, Sydney, Tokyo. Pp:429-482.

Asri- Rezaei, S. and Dalir-Naghadeh, B. (2006): Evaluation of antioxidant status and oxidative stress in cattle naturally infected with Theileria annulata. Veterinary Parasitology. (142) Pp:179-186.

Bailey, R. A. (2008): Design of Comparative Experiments. Cambridge University Press. Pp:116-128.

Bernabucci, U.; Ronchi, B.; Lacetera, N. and Nardone, A. (2005): Influence of body condition on relationships between metabolic status and oxidative stress in periparturient dairy cows. J. Dairy Sci. 88 Pp: 2017-2026.

Bhikane, A.U.; Ghoke, S.S.; Masare, P.S.; Salunke, V.M. and Syed, A.M. (2011): A 


\section{Fayed et al., 2018 (BVMJ-34(3): 57-63)}

new approach in Clinical management of Phosphorus Deficiency Haemoblobinuria $(\mathrm{PDH})$ in Buffaloes. Intas polivet. 12(1) Pp: 56-58.

Brodie, K. G. (1977): Determining arsenic and selenium by atomic absorption spectroscopy-a comparative study. Intern. Lab. Pp: 65-74.

Cappellini, M.D. and Fiorelli, G. (2008): Glucose-6-phosphate dehydrogenase deficiency. Lancet. (371) Pp: 64-74.

Castillo, C.; Hernandez, J.; Valverde, I.; Pereira, V.; Sotillo, J.; Alonso-Lopez, M. and Benedito, J.L. (2006): Plasma malondialdehyde (MDA) and total antioxidant status (TAS) during lactation in dairy cows. Res. Vet. Sci. (80) Pp: 133139.

Chiu, D. T. Y.; Stults, F. H. and Tappel, A. L. (1976): Purification and properties of rat lung soluble glutathione. peroxidase. Biochim. Biophys. Acta. (445) Pp:558566.

Chugh, S.K.; Bhardwaj, R.M.; Mata, M.M. and Malik, K.S. (2000): Therapeutic trials in post-parturient haemoglobinuria of buffaloes with Vitamin E and monitoring of lipid peroxidation in red blood cells. International J. Ani. Sci. 15(2) Pp: 261265.

Dalir-Naghadeh, B.; Seifi, H. A.; Asri-Rezaei, S. and Pilevary, N. (2005): Post-parturient haemoglobinuria in Iranian river buffaloes: a preliminary study. Comp. Clin. Pathol. (14) Pp: 221 - 225.

Dedra, M.; Wandurska-Nowak, E. and Hadas, E. (2004): Changes in the level of antioxidants in the blood from mice infected with Trichinella spiralis. Parasitology Research. (93) Pp:210.

Esterbauer, H.; Cheeseman, K. H.; Danzani, M. U.; Poli, G. and Slater, T. F. (1982): Separation and characterization of the aldehyde products of $\mathrm{ADP} / \mathrm{Fe}+2 \mathrm{C}$ stimulated lipid peroxidation in rat liver microsomes. Biochem. J. (208) Pp: 129140.

Gahlawat, I. (1998): Studies on red cell oxidative stress in relation to treatment of post-parturient haemoglobinuria in buffaloes. M.V. Sc. Thesis. CCS Haryana Agricultural Univeristy, Hisar, India.

Gahlawat, I.; Singh, K. and Kumar, R. (2001): Some clinic-pathological and therapeutic observations in Post- Parturient Haemoglobinuria in buffaloes. Haryana Vet. (40) Pp: 62-65.

Gahlawat, I.; Singh, K. and Kumar, R. (2007): Investigations on oxidative stress in postparturient haemoglobinuria in Buffaloes receiving Sodium Acid Phosphate Therapy. Ital. J. Anim. Sci. 6(2) Pp: 974-977.

rünberg, W. (2008): Phosphorus Homeostasis in Dairy Cattle: Some Answers, More Questions. Tri-State Dairy Nutrition Conference.

Han, B.; Yoon, S.S.; Wu, P.F.; Han, H.R. and Liang, L.C. (2006): Role of selenium in alteration of erythrocyte parameters in bovine fluorosis. Asian Austral. J.Anim. (19) pp.: 665-712.

Heuer, C. and Bode, E. (1998): Variation of serum inorganic phosphorus and association with haemoglobinuria and 


\section{Oxidative Stress and Antioxidant Activity in Buffaloes with Post parturient Hemoglobinuria}

osteomalacia in female water buffaloes in

Pakistan. Prev. Vet. Med. (33) pp.: 69-81.

Hill, S. R.; Knolton, K. F.; Kebreab, E.; France, J.and Hanigan, M. D. (2008): A model of phosphorus digestion and metabolism in the lactating dairy cow. J Dairy Sci. (91) Pp:2021-2032.

Kakkar, P.; Das, B. and Viswanathan, P. N. (1984): A modified spectrophotometric assay of superoxide dismutase. Indian $\mathrm{J}$. Biochem. Biophys. (21) Pp:130-132.

Kelly, W. R. (1984): The abdominal and associated digestive organs. In: Vet. Clini. diagnosis. Bailliere Tindall, London.

Khan, A. and Akhtar, M. Z. (2007): Hematobiochemical and clinico-epidemiological aspects of parturient hemoglobinuria in Nili-Ravi buffaloes. Ital. J. anim. Sci. 6 (2) Pp: 953-956.

Kleczkowski, M.; Klicinski, W.; Sikora, J.; Jdanocviez, M. and Dziekan, P. (2003): Role of antioxidants in the protection against oxidative stress in cattle: nonenzymatic mechanisms. Polish J. Vet. Sci. (6) Pp: 301-308.

Leopold, J. A.; Zhang, Y.Y.; Scribner, A.W.; Stanton, R.C. and Loscalzo, J. (2003): Glucose-6-Phosphate Dehydrogenase Overexpression Decreases Endothelial Cell Oxidant Stress and Increases Bioavailable Nitric Oxide. Arterioscler. Thromb. Vasc. Biol.

Minatel, L. and Carfagnini, J. C. (2002): Evaluation of the diagnostic value of plasma copper levels in cattle. Prev. Vet Med. (53) Pp:1-5.

Morelli, A.; Benatti, U.; Gaetanio, G. F. and De Flora, A. (1978): Biochemical mechanisms of glucose-6-phosphate dehydrogenase deficiency. Proc. Nati. Acad. Sc. USA. 75(4) Pp: 1979-1983.
Nishikimi, M. Appaji, N. and Yagi, K. (1972): The occurrence of superoxide anion in the reaction of reduced phenazine methosulfate and molecular oxygen. Biochem. Biophys. Res. Commum. 46(2) Pp: 849-854.

Nobrega-Pereira, S.; Fernandez-Marcos, P. J.; Brioche, T.; Gomez-Cabrera, M. C.; Salvador-Pascual, A.; Flores, J.M.; Vina, J. and Serrano, M. (2016): G6PD protects from oxidative damage and improves healthspan in mice. Nature communications.

Ronchi, B.; Bernabucci, U.; Lacetera, N. and Nardone, A. (2000): Oxidative and metabolic status of high yielding dairy cows in different nutritional conditions during the transition period. In: Proceedings of 51st Annual Mtg. E.A.A.P., Vienna. Pp: 125.

Santra, A.; Maiti, A. and Chowdhury, A. (2000): Oxidative stress in liver of mice exposed to Arsenic contaminated water. Indian J. Gastroentero. (19) Pp: 112-115.

Sarma, K.; Saravanan, M.; Kumar, P.; Kumar, M.; Jadav, R.K. and Mondal, D.B. (2014): Influence on haemato-biochemical and oxidative indices of post parturient haemoglobinuric (PHU) buffalo. Buffalo Bulletin. 33(4).

Singh, R.; Singh, K.; Rana, Y.S. and Beniwal, B.S. (2005): Reduced glutathione activity in buffaloes suffering from post-parturient haemoglobinuria. Vet. Practitioner. 6 (2) Pp: 135-137.

Veldman. J.E, Desiderio. P, David. J.L, Meret. S. and Henkin. R.I (2000): Simultaneous direct estimation by atomic absorption spectrophotometry of copper and zinc in serum, urine and cerebrospinal fluid. Clin. Chem. 